Article

\title{
Misión Integral and Progressive Evangelicalism: The Latin American Influence on the North American Emerging Church
}

\author{
Michael Clawson \\ Department of Religion, Baylor University, Waco, TX, 76798, USA; \\ E-Mail: Mike_Clawson@baylor.edu; Tel.: +1-512-917-1501
}

Received: 14 June 2012; in revised form: 12 August 2012 / Accepted: 17 August 2012 /

Published: 23 August 2012

\begin{abstract}
Though commonly identified with the conservative politics of the Christian Right, over the past decade evangelicals in the United States have increasingly embraced a more politically progressive range of social concerns. Often treated as something wholly new, this trend actually has roots in Latin American evangelicalism from the 1970s. Latin American theologian/practitioners like C. René Padilla and Samuel Escobar of the Latin American Theological Fellowship, promoted a holistic vision of the church's mission, what they called misión integral, seeking to integrate both evangelism and socio-political involvement on behalf of the poor and oppressed. These Latin American thinkers played a direct role in the rise of progressive evangelicalism in the United States in the 1970s. While overshadowed for a time by the Christian Right, the concept of mision integral and its Latin American exponents has continued to influence the resurgence of progressive social concerns among North American evangelicals in the first decade of the 21st century, and especially those associated with the emerging church movement.
\end{abstract}

Keywords: evangelicalism; progressive evangelicalism; Latin American evangelicalism; emerging church; emerging Christian movement; integral mission; holistic mission; misión integral

\section{Introduction}

Although commonly associated with the conservative politics of the Christian Right, over this past decade evangelicals in the United States have increasingly embraced a much broader range of social concerns, including many typically associated with the political Left: environmental protection, 
concern for the poor and economic justice, anti-militarism and peacemaking, and immigration reform [1-4]. Often treated as something wholly new, this movement, sometimes referred to as "progressive evangelicalism," actually has roots in trends dating back to Latin America in the 1970s. Latin American theologian/practitioners such as C. René Padilla and Samuel Escobar of the Latin American Theological Fellowship (FTL_Fraternidad Teológica Latinoamericana), promoted a holistic vision of the church's mission, what they called misión integral, seeking to integrate both evangelism and socio-political involvement on behalf of the poor and oppressed [5,6]. These Latin American thinkers played a direct role in the rise of a progressive, prophetic evangelicalism in the United States in the 1970s, and while this movement was overshadowed for a time by the Christian Right, the concept of misión integral and its Latin American exponents have continued to influence the resurgence of progressive social concerns among evangelicals in the first decade of the $21^{\text {st }}$ century.

\section{The Beginnings of the FTL and Misión Integral}

In October 1969 the Billy Graham Evangelistic Association (BGEA) gathered theologians, leaders and mission workers in Bogotá, Colombia for the Primer Congreso Latinoamericano de Evangelizacion (CLADE I) to promote the task of evangelization in Latin America. From the beginning everything about the conference seemed "Made in America": the planning, finances, program, speaker invitations, and similar decisions were all steered by the interests of the North American organizers [7]. In particular, the conference seemed premised on the concern of North American evangelicals to oppose the Tercera Conferencia Evangélica Latinoamericana (CELA III) held earlier that year by the World Council of Churches (WCC). In the eyes of the BGEA, a battle for the church in Latin America was being fought between the liberal, ecumenical promoters of the social gospel, and conservative evangelicals like themselves who emphasized personal conversion to Christianity as the solution to both individual and social sin [8,9]. To prepare the groundwork for this polemic purpose, a book by North American missiologist C. Peter Wagner, Latin American Theology: Radical or Evangelical? was distributed to all participants in advance of the conference [10].

In the eyes of many Latin American theologians, however, the situation was much more complex than Wagner's two-party characterization of the church in Latin America or his proposed "church growth" solutions. Their desire to produce a truly Latin American approach to evangelical theology-one that embraced a clear call to socio-political engagement in response to the stark human needs evident in Latin America-led a handful to organize their own meeting of Latin American theologians the following year in Cochabamba, Bolivia. As one participant, Samuel Escobar, put it, they were "tired of the evangelical power centers in North America telling us how to think, who to read, and what it meant to be evangelical," and therefore, "we decided it was time to start reflecting the faith as grownups and on our own" [11]. Through this meeting, the FTL was born under the founding leadership of Samuel Escobar, René Padilla, Peter Savage, Pedro Arana, Emilio Antonio Nuñez, Orlando Costas, and Rolando Gutierrez [12].

This new fellowship developed an integral theology of mission, that is, one which would relate their understanding of the gospel and the mission of the church to the Latin American experience of extreme poverty, political oppression, and widespread despair. Up to this time, evangelicals had achieved most of their numerical growth in Latin America by promising extra-worldly spiritual rewards beyond this 
life of suffering, rather than political, social, or economic justice in the here and now [12,13]—an individualistic and otherworldly emphasis largely inherited from North American fundamentalist missionaries averse to anything resembling the "social gospel" of their liberal modernist opponents. At the same time, the spread of liberal Protestantism in the region had been stifled by a growing conviction among the more ecumenical denominations that Latin America needed no more foreign missionaries since it had already been sufficiently Christianized by the Catholic Church ([14], pp. 24, 25, 41). The result was an increasing drift toward conservatism among Latin American Protestants, as only anti-Catholic fundamentalists continued to send evangelistic missions to the region. FTL theologian Emilio Núñez notes that these missionaries were "pre-millenarian in eschatology, Pietist in their vision of Christianity, and separatist in their basic attitude toward other ecclesiastical bodies and toward society in general." Because of this, Núñez argues, such missionaries were ill-equipped to deal with the challenges of poverty and systemic injustices ([15], pp. 374-379).

The FTL took up this challenge by engaging with the theologies of liberation being put forth by their Catholic and liberal Protestant counterparts. Earlier in the decade a group of theologians connected with the WCC had formed a working group Iglesia y Sociedad en América Latina (ISAL) to address the question of Christian responsibility in the face of rapid social, political, and economic change ([16], p. 65). In subsequent years ISAL came to consciously adopt a Marxist analysis and interpretation ([17], p. 55) and their writings came to represent or influence much of the concurrent development of liberation theology in Latin America. As ISAL gradually became more radical, however, many of the theologians associated with the FTL felt the need to provide a more moderate and evangelical alternative that nevertheless acknowledged the important questions and challenges raised by ISAL. René Padilla wrote that Isaline errors were "due to the fact that it begins with the revolutionary situation and interprets the Scriptures on the basis of presuppositions derived from leftist ideologies... The result is a secularized Gospel the dominant notes of which coincide with notes of Marxist tone" ([15], p. 80). Padilla and his colleagues wanted to respond to the same realities addressed by liberationists while still upholding their evangelical commitments to the authority of scripture, the divinity of Christ, and the necessity of evangelism ([14], p. 114). Their response was not merely critical. Padilla would write elsewhere that "The question for me is not, How do I respond to liberation theology, so as to show its flaws and incongruities? But rather, How do I articulate my faith in the same context of poverty, repression and hopelessness out of which liberation theology has emerged?" ([18], p. 40) Their solution emphasized an incarnational and kingdom-centered Christology. Integral mission, Padilla wrote, is "the concrete expression of a commitment to Jesus Christ as Lord of the totality of life and of all creation" ([19], p. 20). Because Jesus is Lord over all of creation and all spheres of life, there is no real distinction between serving "spiritual" needs and serving "physical" needs, thus the mission of the church cannot simply be reduced to making religious converts but must include action on behalf of the poor and in service of social justice.

\section{The Rise of Progressive Evangelicalism in the 1970s}

\subsection{Missionary Movements and Two-Thirds World Exposure}

These ideas did not stay confined to Latin America for long, and once communicated to North Americans, they found an audience already hungry for a more integral expression of evangelical 
mission. While a vague concern for social ethics was not unheard of among North American evangelicals prior to the 1970s, few considered it to be as important as personal evangelism [20,21]. These perspectives began to change during the 1960s and 70s as many younger evangelicals were exposed to the realities of poverty and social oppression through their short term missions experiences in the Two-Thirds World. The postwar economic boom had enabled dozens of evangelical organizations like Campus Crusade, InterVarsity, Latin America Mission, Pioneer Girls, and Youth with a Mission, to send thousands of young Christians to the Two-Thirds World for short-term trips in the 1950s and 60s. Though typically focused on "soul-winning," the extreme poverty and challenging social conditions these young missionaries encountered in such places opened their eyes to broader realities and motivated them to engage with social and political issues back home as well, often in ways that led them beyond the bounds of conservatism ([22], pp. 106-153).

Even for those remaining in the United States, exposure to Two-Thirds World perspectives came by way of mission conferences, Christian colleges, and evangelical student ministries that hosted and highlighted international voices with their condemnations of American imperialism, consumerism, and antipathy towards social justice. At Wheaton College for instance, a flagship school of the evangelical movement, the student newspaper contained numerous articles by international students on issues of global politics and social issues during the 1960s and 70s. The college itself also offered opportunities like the Student Missionary Project and the Human Needs and Global Resources (HNGR) degree program which exposed hundreds of students to international development work ([22], pp. 116-117). Similar trends were evident at other evangelical schools.

Two-Thirds World voices were also increasingly present at evangelical missions conferences. At the 1966 Congress on the Church's Worldwide Mission (Wheaton '66) recommendations from Two-Thirds World participants produced a breakthrough statement urging evangelicals "to stand openly and firmly for racial equality, human freedom, and all forms of social justice throughout the world" ([23], p. 235; [24]). Likewise, the theme at InterVarsity's tri-annual Urbana Missions conference in 1970 was "Christ the Liberator" where multiple speakers spoke to "the largest student missions convention ever held" of the need for the church to confront war, racism, and poverty ([25]; [26], pp. 92-94). Samuel Escobar, first president of the newly formed FTL, caused a stir in his talk on "Social Concern and World Evangelism," as he informed the 12,000 attendees that in some parts of the world, "Christianity has become synonymous with a gay, unconcerned and irrelevant selfishness and Communism synonymous with a committed, disciplined, sacrificial way of living," but that they could "witness to the power of God to liberate us from sin, if we are able also to show by word and deed that we are being liberated from those sins of social injustice, social prejudice, abuse and selfish individualism" ([27], pp. 104, 108). Three years later, alongside another major address by Escobar, a fellow Latin American, Colombian Gregorio Landero, also told Urbana 73 participants that "the human race cannot get along just on spiritual ministry; we must minister to the material needs also" ([28], p. 11), and Urbana 76, attended by over 17,000 students, specifically focused on Two-Thirds World concerns ([29], pp. 102-103). 


\subsection{Radical Politics and Evangelicals}

The radical politics of the 1960s also helped prepare the ground among North American evangelicals for an appropriation of integral mission theology. Increasingly, younger evangelicals especially found themselves swept up in the tumultuous social movements of the day-Civil Rights and opposition to Vietnam chief among them. The convergence of radical politics with evangelical faith produced a breed of Christians who learned to apply their evangelical theology not just to issues of personal salvation and individual morality, but also to socially structured crises like racial injustice, militarism, poverty, gender issues, and ecology. In contrast to the older generation of evangelical leaders, these progressive evangelicals tended to look beyond the usual assumption that "changed individuals alone can bring about a transformed society," and began asking what specific social transformations such changed individuals might legitimately begin working toward ([26], p. 36; [30]; [31], p. 181).

Although initially catalyzed by both Civil Rights $t$ and the anti-war movement, ${ }^{1}$ in the Latin American theologians of the FTL these socially progressive evangelicals soon found natural allies who offered an already developing theology of integral mission to express their shared concerns. While many of the more radical theologies of liberation also being formed around this time-black and feminist for instance, as well as Latin American-were largely rejected or simply ignored by mainstream North American evangelicals for being too rooted in modernism, ecumenism, and Marxism, the more moderate theologians of the FTL enabled progressive evangelicals to translate their social concerns for a more theologically conservative audience. Samuel Escobar, for instance, lent a Latin American perspective to the 1973 Thanksgiving Workshop on Evangelicals and Social Concern held in Chicago. This workshop was attended by nearly fifty evangelical leaders, including many rising stars among the younger progressive evangelicals and a number of influential older evangelicals [33] ${ }^{2}$. These leaders produced the Chicago Declaration of Evangelical Social Concern, putting forth clear condemnations of racism, sexism, militarism, civil religion, materialism, and economic injustice from an evangelical standpoint, and garnering much attention in both the mainstream and Christian press [33-39].

Progressive evangelicals continued to listen to and learn from these Latin Americans in the years following the Thanksgiving Workshop. A September 1976 issue of Jim Wallis' Sojourners magazine, for instance, centered on Latin American liberation theologies, including an interview with Escobar [40] and a lengthy review of the book, Doing Theology in a Revolutionary Situation, by Jose Miguez Bonino, another FTL theologian [41]. Elsewhere that same year Wallis favorably cited René Padilla's statements on radical discipleship ([42], p. 13). Orlando Costas, another prominent FTL theologian,

1 Jim Wallis, one of the key leaders of prophetic evangelicalism from the early 1970s till the present day, relates his own perhaps stereotypical journey in this regards in his memoir Revive Us Again [32], describing his journey from a conservative evangelical background into Civil Rights and anti-war activism, and then back into the evangelical world with a reawakened social conscience.

2 Significant younger leaders present included Tony Campolo, Donald Dayton, Sharon Gallagher, Richard Mouw, Bill Pannell, Richard Pierard, John Perkins, Ronald Sider, Tom Skinner, Lewis Smedes, Jim Wallis, Robert Webber, and Merold Westphal. Older leaders included Myron Augsburger, William Bentley, Frank Gaebelein, Vernon Grounds, Carl Henry, Rufus Jones, Carl Thomas MacIntire, Jr., Bernard Ramm, Paul Rees, and John Howard Yoder ([33]; [34], p. 3). 
was contributing editor for the progressive evangelical journal The Other Side during this time, and in 1974 authored The Church and Its Mission: A Shattering Critique from the Third World, [43] garnering significant attention among North American evangelicals [44]. The Latin American influence on the rise of progressive evangelicalism was such that in his 1974 describing these young, progressive evangelicals Richard Quebedeaux could lead off the chapter on the "Backgrounds to the New Discontent" with a quote from Samuel Escobar ([26], p. 55). Four years later, in his follow up book, The Worldly Evangelicals, Quebedeaux would devote several pages to the impact of evangelical Latin American liberation theology, specifically naming Bonino, Escobar, Padilla, and Costas as important influences on progressive evangelicalism ([29], pp. 111-113).

\subsection{The Lausanne Movement}

With the ground prepared by these prior trends, the most significant and lasting impact of Latin American integral mission theologians on North American evangelicalism came through the International Congress on World Evangelization held in Lausanne, Switzerland in July 1974 (Lausanne '74). Initiated by Billy Graham and other prominent evangelical leaders, Lausanne was described by Time magazine as "a formidable forum, possibly the widest-ranging meeting of Christians ever held"-nearly 2,500 participants and 1,000 observers from 150 countries and 135 Protestant denominations [45]. Lausanne, "burst upon us like a bombshell," according to one participant. "It became an awakening experience for those who attended and thousands of Christians in numerous countries who read about it" ([46], p. vii). The 2700-word statement on evangelism that it produced, the Lausanne Covenant, has become a point of unity among evangelicals worldwide in the decades since. Hundreds of organizations today still use the Lausanne Covenant as their statement of evangelical commitment [47].

Though originally conceived as a challenge to the World Council of Churches' emphasis on social concerns rather than personal conversion [48], the relationship between evangelism and social problems quickly became a recurring and prominent theme at Lausanne, due in large part to provocative and widely discussed plenary addresses given by Samuel Escobar and René Padilla. Padilla spoke on "Evangelism and the World," condemning the too-common identification of Christianity with "the American Way of Life" and yet also reminding participants that "evangelism cannot be reduced to the verbal communication of doctrinal content, with no reference to specific forms of man's involvement in the world" [49]. Afterwards, one journalist described Padilla's address as "the best theological presentation of the congress," [50] and Time called it "one of the meeting's most provocative speeches" [45]. A few days later, Escobar spoke on "Evangelism and Man's Search for Freedom, Justice, and Fulfillment," a strong statement in favor of integral mission, in which he affirmed that evangelism and social action were "inseparable" [51]. Much to the surprise and chagrin of the more conservative organizers, these addresses made a huge splash at the Congress. Some described the emphasis on social concerns as a "major breakthrough" [50] and "a coming of age for evangelicals" [52]. Others specifically noted that Escobar and Padilla's papers had been "subject to more comment than all the other papers put together" [53], and credited them with causing a "significant shift in Christian thinking" that "really set the Congress alight" ([54], p. 91). Even Billy Graham, who seemed determined to keep Lausanne focused primarily on personal evangelism [55], 
noted afterward that "if one thing has come through loud and clear it is that we evangelicals should have social concern. The discussion in smaller groups about the contemporary meaning of radical discipleship has caught fire" ([54], pp. 90).

The smaller group to which Graham referred was an impromptu meeting of some 500 people to discuss the issue of radical discipleship. After much discussion this informal group created a document, A Response to Lausanne [56], which Padilla called "the strongest statement on the basis for holistic mission ever formulated by an evangelical conference up to that date," insofar as it defined the gospel as "Good News of liberation, of restoration, of wholeness, and of salvation that is personal, social, global and cosmic" ([57], p. 11). Because of such initiatives, the final form of the Lausanne Covenant included not just one sentence on social concerns, as some of the more conservative conveners had originally intended, but an entire section on "Christian Social Responsibility," which stated that while "reconciliation with man is not reconciliation with God, nor is social action evangelism, nor is political liberation salvation, nevertheless we affirm that evangelism and socio-political involvement are both part of our Christian duty... the salvation we claim should be transforming us in the totality of our personal and social responsibilities" ([58], pp. 4-5). While such a statement was less radical than what some had hoped for, it was nevertheless seen by many as indicative of a new direction for the evangelical movement ([59], p. 173; [60], p. 136).

Others among the North American missions establishment, however, thought the Lausanne Covenant had gone way too far, seeing the direction of the Congress as a dangerous slide towards ecumenism and the social gospel [61], and the emphasis on social action as a "torpedo" threatening to scuttle the central project of world evangelization [62]. Prominent leaders such as Harold Lindsell and Billy Graham took pains to minimize the importance of the Congress' focus on social concern $[53,63]$. The tension between these conservative voices and those desiring an even more radical statement on integral mission would play out over the next decade in a series of ongoing mission conferences and theological consultations. Some gatherings, the 1980 Consultation on World Evangelization in Pattaya, Thailand for instance, attempted to move the pendulum away from the Lausanne Statement on Social Responsibility and towards a reaffirmation of the primacy of evangelism as the mission of the church ([6], pp. 43-48; [57]; [60], pp. 141-144; [64]; [65], pp. 135-161). Other forums, however, sought to reaffirm the emphasis on social action alongside evangelism, and to clarify the relationship between the two $[54,66,67]^{3}$. These culminated in the 1983 Consultation on the Church in Response to Human Need held at Wheaton College (Wheaton '83). Sponsored by both the Lausanne Continuation Committee and the World Evangelical Fellowship, Wheaton '83 produced a landmark document [68] that Padilla himself regarded as "the strongest evangelical affirmation of commitment to integral mission in the last quarter of the twentieth century" ([69], p. 55). South African missiologist David Bosch further noted that, "For the first time in an official statement emanating from an international evangelical symposium, the perennial dichotomy [between evangelism and social involvement] was overcome" ([70], p. 407).

3 Gatherings sponsored by the Lausanne Movement to discuss this issue include the Consultation on Gospel and Culture at Willowbank, Bermuda (1978), the International Consultation on Simple Life-style at Hoddesdon, England (1980), and the Consultation on the Relationship Between Evangelism and Social Responsibility at Grand Rapids, Michigan (1982). 
It seems clear that, in the words of one historian, "the Latin Americans gave the Lausanne Movement an agenda for the following decade after Lausanne" ([71], p. 160), and that because of their influence at Lausanne 74 and afterwards, the global evangelical movement became more attuned to the need for an integral approach to both evangelism and social justice. Many rising North American progressive evangelical leaders were present at or aware of these events, ${ }^{4}$ and it is not hard to see a connection between their social activism and the integral mission theology first developed among Latin Americans. Beyond the direct influence of Latin American integral mission theology, the Lausanne Movement also significantly affected the rise of progressive evangelicalism in the United States by legitimating engagement in social ministries and progressive political activism within the broader evangelical movement. With major evangelical leaders like Billy Graham and John Stott lending their stamp of approval to statements on Christian Social Responsibility and Radical Discipleship, such concepts entered the mainstream of evangelical dialogue and became acceptable evangelical theologies not just for Latin Americans, but North American evangelicals as well.

\section{The Re-emergence of Progressive Evangelicalism in the $21^{\text {st }}$ Century}

\subsection{The Decline of Progressive Evangelicalism}

Despite this mainstream acceptance, during the 1980s and 90s the rise of the New Christian Right overshadowed the influence of integral mission theology among evangelicals in the United States ([75], pp. 111-147). The secular conservative backlash to the radical social reforms of the 1960s and 70s was paralleled by (or perhaps even produced) a resurgence of social and theological conservatism within the evangelical movement as well, as marked by the emergence of "family values" leaders such as James Dobson, Jerry Falwell, and Pat Robertson and the potent media outlets they controlled. Though sharing the progressive evangelicals' willingness to engage with socio-political issues, the primary concerns of these conservative leaders were markedly different than those of the Chicago Declaration signers - mostly issues of sexual morality or questions concerning the relation of church and state. The concerns which had motivated the rise of progressive evangelicalism-poverty and economic justice, American militarism and imperialism, gender and racial equality, ecology, etc.- - were either neglected by the Christian Right, or, more commonly, seen as part of a "liberal agenda" that in their view was to blame for the moral and spiritual decline of American society. Increasingly over the last two decades of the twentieth-century, North American evangelicalism became associated, in both perception and actuality, with the conservative politics of the Christian Right [76].

At the same time, the more progressive evangelical movement declined in cohesion, influence, and popular support. David Swartz argues that the right-ward turn in evangelicalism coincided with an increasing fragmentation among the forces of the "evangelical left" due to the tensions created by burgeoning identity politics in the late seventies and early eighties [77]. It became increasingly difficult for progressively-minded white males, evangelical feminists, racial reconcilers, and other

\footnotetext{
4 Among those progressive evangelicals present at one or more of the Consultations were David Bosch, Donald Dayton, Leighton Ford, Richard Foster, Richard Hays, William Pannell, John Perkins, Clark Pinnock, Ronald Sider, Tom Sine, and John Stott. Latin American FTL theologians present include Orlando Costas, Gregorio Landero, Emilio Nunez, C. René Padilla, and Peter Savage [72-74].
} 
minority or interest groups to see themselves as part of a broader coalition when their concerns seemed constantly to compete with one another for attention and extremely limited resources. For these reasons, many progressive evangelical leaders and organizations remained relatively minor players within the evangelical world throughout the last quarter of the twentieth century. By the late 1990s some progressive evangelical leaders were lamenting a perceived disconnect between more moderate, socially concerned mission organizations and colleges, and the broader, more socially conservative “evangelical rank and file" ([78], pp. 132-33).

North Americans also seemed to lose interest in Latin American theologies of integral mission after the early 1980s, as many mainstream evangelicals came to interpret the former as a dangerous slide towards Communism, liberal theology, and the social gospel ([71], pp. 189-94). When the Second International Congress on World Evangelization (Lausanne II) was held in Manila, Philippines in 1989, many perceived a deliberate effort on the part of its North American organizers to move the conversation away from integral mission, back toward the primacy of evangelism alone ([79], pp. 83-84; [80], pp. 38-39; [81], p. 52). Over a decade later progressive evangelicals Tom and Christine Sine would comment that "an integrated approach to mission has been losing ground in recent years... as a number of evangelicals in the United States have embraced a view of social responsibility shaped by the religious and political right that largely ignores social justice issues" ([82], p. 73).

\subsection{Resurgence of Social Concerns among Mainstream Evangelicals}

Despite such signs of marginalization and decline, the ideas of integral mission remained a present, if diminished, influence within North American evangelicalism. Progressive evangelicals kept a toe-hold in certain key locations within the evangelical world, most importantly in its seminaries and liberal arts colleges as well as prominent youth and campus ministries ([29], pp. 84-114). From these centers of influence, over the past four decades prophetic evangelicals have been able to mold many up-and-coming evangelical leaders into a more socially engaged expression of faith. As in the 1960s and 70s, evangelical students during the 1980s and 90s were still being introduced to the realities of poverty and social injustice through short term mission experiences and in their colleges and student ministries. Unlike these earlier decades however, younger evangelicals in the later years of the twentieth century had greater access to a mature and established theology of integral mission and the numerous ministries focused on issues of social justice developed by the earlier generation of prophetic evangelicals. This theology was especially developed and promoted by The International Fellowship of Evangelical Mission Theologians (INFEMIT). Founded in 1987, but with roots back to 1980, INFEMIT provides leadership development for mission groups, furthers research on the theology and practice of integral mission on local, regional, and international levels, and has worked to increase collaboration around these ideas between church leaders in the Two-Thirds World and those in the West ([6], pp. 71-82). The Micah Network also represents another major organization dedicated to connecting global evangelical agencies engaged in integral mission. Formed 1999, the Micah Network now includes over 500 member organizations worldwide. Besides issuing the Micah Declaration on Integral Mission, the Micah Network has helped coordinate evangelical support for the United Nations Millennium Development Goals [83,84]. The theological and institutional groundwork laid by the 
preceding generation through institutions like INFEMIT, the Micah Network, and many others, has made possible the re-emergence of progressive evangelicalism in the first decade of the $21^{\text {st }}$ century.

Increasingly, evangelical leaders of all stripes, not just those explicitly associated with progressive evangelicalism, have developed a new passion for progressive social concerns [1-4]. While traditional opposition to abortion and same-sex marriage remain high, a large majority (73\%) of evangelicals now also support tougher environmental protections, and a solid majority (54\% to 39\% opposed) favor additional government assistance for the poor [85]. This shift in concern towards the environment and the poor, along with other progressive issues, can also be seen in a watershed document released by the National Association of Evangelicals in 2005, For the Health of the Nation: An Evangelical Call to Civic Responsibility, which favored "effective governmental programs and structural changes" for a just economy, fairer trade and foreign policies aimed at reducing global poverty, support for human rights and religious liberty, encouragement for Christians to engage in practical peacemaking and for governments to restrain the use of military force, and a strong endorsement of environmental stewardship [86]. This was followed by the NAE's endorsement of “An Evangelical Declaration Against Torture" (2007) [87], along with calls for immigration reform to protect human dignity (2009) [88] and for lowering the national debt without abandoning commitments to the poor (2011) [89]. Though not an official NAE statement, 2006 saw the release of "Climate Change: An Evangelical Call to Action," a statement endorsed by eighty-six influential evangelical leaders [90]. This was followed in 2008 by the "Evangelical Manifesto: A Declaration of Evangelical Identity and Public Commitment," signed by over seventy prominent leaders, calling for the "expansion of our concerns beyond single-issue politics, such as abortion and marriage, and a fuller recognition of the comprehensive causes and concerns of the Gospel" such as violence, racism, poverty, and pandemic diseases [91].

The resurgence of progressive evangelicalism is also evident in the attention paid to such issues by prominent mega-church leaders from across the evangelical theological spectrum and across the country-from the Neo-Reformed Tim Keller at Redeemer Presbyterian in New York City [92], to seeker-sensitive Bill and Lynne Hybels at Willow Creek in the Chicago suburbs [93] and purpose-driven Rick Warren at Saddleback Community Church in Orange County, California [94], to the emergent Rob Bell until-recently of Mars Hill Bible Church in West Michigan [95]. At the same time, numerous parachurch organizations focusing on advocacy for various social causes, or on domestic and foreign missions to serve the urban poor, have sprung up in the past decade ([6], pp. 71-97; [83,84]). Editorial trends in Christianity Today magazine, the flagship publication of the evangelical movement, also reflect this shift. For instance, the percentage of articles on social justice and ecological concerns in $C T$ 's editorial pages since 2004 has more than tripled compared to the previous eight years. ${ }^{5}$

Publishing trends also bear witness to the growing interest in social justice among evangelicals. Despite George W. Bush's 2004 re-election with the support of nearly 79\% of white evangelicals ([96], p. 7), Jim Wallis' 2005 book God's Politics, with its strong critique of the politics of the Religious Right, remained on the New York Times Bestseller list for four months [97]. Readers and the media alike seemed captivated by what to them appeared to be a unique example of a socially progressive evangelical. The renewed popularity of this elder statesman of progressive evangelicalism likely

These percentages are based on an as yet unpublished study, conducted by the author, of political editorials in Christianity Today over the past 25 years. 
indicated a growing, though previously unexpressed, dissatisfaction among evangelicals with the politics of the Religious Right, and a hunger for a broader evangelical approach to politics and social engagement. Wallis himself claims that God's Politics was "the right book at the right time," to spark a "new conversation about faith, values, and politics in America," noting that in the years following the book's publication, he had the opportunity to "speak directly to hundreds of thousands of people, reach millions more through media coverage, and have many conversations with America's political leaders on both sides of the aisle" about peace and social justice ([98], pp. 33-34). Since the success of Wallis' book, evangelicals have eagerly embraced numerous similar books encouraging them to practices of social justice and lifestyles of radical discipleship (e.g. [99,100]). Given the popularity of such books and the increasing attention given to social justice by evangelical leaders and organizations in recent years, it seems reasonable to conclude that both the evangelical leadership and the evangelical rank and file have reawakened to a more integral view of the gospel and a renewed embrace of progressive social concerns.

\subsection{The Emergent Turn toward Integral Mission}

If the resurgence of prophetic evangelicalism among North Americans in the early $21^{\text {st }}$ century has been an unexpected flowering of the integral mission ideas implanted by Latin Americans some forty years ago, the emerging Christian movement represents a more direct line of influence. ${ }^{6}$ Emerging Christianity is a movement that has gradually taken shape across numerous Christian traditions over the past several decades. Though extremely diverse and therefore difficult to define, one possible description is that emergents are those Christians who have been questioning their received traditions, institutional structures, and theologies in light of recent postmodern shifts in the broader culture, ${ }^{7}$ and are beginning to create new expressions of the faith adapted in various ways and in varying degrees to this new context [101].

Among North American evangelicals, the emerging conversation began in the late-1990s as an attempt to "contextualize" the gospel to the younger generations - a term which is itself related to the concept of integral mission, and springs from the same Two-Thirds World sources, including the Latin American theologians of the FTL ([6], pp. 83-93; [60], p. 74; [102]). Soon, however, the conversation moved away from discussions about contextual worship styles and ministry methods into deeper waters of postmodern epistemology and theological re-evaluation ([103], pp. 41-48). This led, in turn, to questioning the nature of the gospel message itself, and it was in this discussion that emergents began first to encounter integral mission ideas. Popular missiologists like Darrell Guder, Leslie

6 I prefer the term "emerging Christianity" over the more common label "emerging church," which can give the misleading impression that the movement is simply a new splinter group or a singular institutional entity rather than a transformation that is happening within and amongst numerous segments of Christianity. Participants in this movement will be referred to as "emergents," though this should not be confused with "Emergent Village," a 501c3 organization which exists as but one semi-institutional expression of the broader emerging Christian movement.

7 "Postmodern" is a complex term with many diverse connotations depending on the field in which it is used. For this paper I will be referring to postmodernity as a socio-cultural trend in Western societies characterized by a suspicion towards Enlightenment ideals of rationalism and social progress, a pluralistic blending of diverse beliefs, styles, and cultures, a flattening of hierarchies, and the decentering of other traditional sources of authority. 
Newbign, David Bosch, Tom Sine, and John Stott had adapted for Western audiences the integral mission ideas originally put forth by the FTL, and were being read in the 1990s and early 2000s by many leaders in the emerging Christian movement. Sine in particular has helped connect the earlier integral mission conversation with the new emerging movement - as he has been present both with Padilla and others at the 1983 Wheaton Conference (out of which experience he wrote his 1987 book Why Settle for More and Miss the Best? to translate integral mission ideas for a lay, North American audience) and later in friendship and dialogue with emergent leaders [104]. These authors have inspired many emergents to reimagine the church as existing to serve the world in a more holistic way. Early signs of this reimagining include the talk Jim Wallis gave at the 2004 Emergent Convention, which Tony Jones recalls as having a "big effect" on the movement [105]. Through such influences, the emergent conversation gradually turned toward an explicit emphasis on social justice as integral to the meaning of the gospel and the mission of the church.

The connection between Latin American integral mission theology and the emerging church movement became even more direct, however, through the person of Brian McLaren, who stands out as the single most influential emergent leader. McLaren first became aware of integral mission ideas in the 1970s through reports on the Lausanne gathering. He describes "feeling a certain thrill that there was a section of the document called Christian Social Responsibility," and suggests that despite the lukewarm reception among American evangelicals, twenty-five years after Lausanne the time may have finally arrived for "a global, Christ-centered, cross-confessional, justice-oriented spiritual/social movement to be born" - a movement he identifies, in part, with the emergent conversation ([106], p. 14). Beyond this initial exposure, McLaren also tells of how he personally became acquainted with the Padilla family when René's daughter Elisa attended his church in Maryland from 2002-2004 [107]. She challenged him to address issues of economic justice more substantially and eventually introduced McLaren to her father. The elder Padilla invited McLaren to travel with him in Latin America for several months in 2005 and 2006, during which time Padilla mentored him in Latin American theology. Though these trips McLaren was also introduced to Tomas and Dee Yaccino and Robert Guerrero, leaders of La Red del Camino para La Misión Integral en America Latina, a network of Latin American churches and church leaders committed to the practice of integral mission in their local contexts [108]. McLaren would develop a friendship and partner with these leaders for further events and projects. According to McLaren, these connections have been highly significant to the development of his thought, and have greatly influenced most of his writings since at least 2005, including his most explicit work on social justice and integral mission to date, Everything Must Change: Jesus, Global Crises, and a Revolution of Hope [109], which he completed while traveling with Padilla in Central and South America [110].

Through McLaren's books and numerous speaking engagements, these ideas have filtered into the rest of the American emerging movement. In his sessions at the 2005 Emergent Convention, McLaren introduced his audience to the term misión integral (explaining it by analogy to pan integral, the Spanish term for whole-wheat bread, hence, in McLaren's words, "whole-wheat mission") and asserting that misión integral was essentially the same as what North American emergents were likewise attempting to work out in their new postmodern re-envisioning of the gospel [111]. Likewise, Everything Must Change became the basis for a series of 12 conferences in cities around the United States in the Spring of 2008, during which McLaren was able to spur discussions about social justice 
and integral mission among thousands of participants [112]. Because of McLaren's central leadership role among emergents, his appropriation of integral mission theology and his own shift towards greater political activism for social justice have had a significant impact on the emergent movement as a whole ([103], pp. 49-51), in one sense making the emergent movement a direct, North American descendant of both the Latin American theology of the 1970s and the progressive evangelicalism which it inspired and informed.

\section{Summary and Conclusion}

In the four decades since the theology of integral mission sprouted in Latin American evangelical circles, it has been embraced by many evangelical theologians and practitioners worldwide. In this way Latin American theologians have led the way for global reflection on the mission of the church, an increased emphasis on social concerns among evangelicals, and a transformation in the traditional conception of the gospel itself. These theologians were key influences in the rise of progressive evangelicalism in the 1970s, and played an essential role in the addition of a social plank to the 1974 Lausanne Covenant, thereby legitimating subsequent emphases on social ministries among mainstream North American evangelicals. While these more socially progressive elements were overshadowed in the 1980s and 90s by the rise of the New Christian Right, Latin American evangelical theologians have contributed to the recent resurgence of social concerns among North American evangelicals through their ongoing witness to the need for an integral understanding of the gospel, and their relational connections to the emerging Christian movement. Given this resurgence, one could argue that North American evangelicals are just now catching up to what theologians in Latin America have been practicing for the past forty years. The seeds of integral mission planted by Escobar, Padilla and others in the 1970s are beginning to bear tremendous fruit in the North American church, and especially among those who consider themselves emergent Christians.

\section{Acknowledgements}

Thanks are due to Tony Jones, Brian McLaren, and Tom Sine for graciously granting interviews regarding this topic. I am also grateful to many of my colleagues at Baylor University, and especially Barry Hankins and Bill Pitts, who provided invaluable feedback on an earlier draft of this paper.

\section{References}

1. David Gushee. The Future of Faith in American Politics: The Public Witness of the Evangelical Center. Waco: Baylor University Press, 2008.

2. David Kirkpatrick. “The Evangelical Crackup.” New York Times Magazine, 28 October 2007.

3. Marcia Pally. The New Evangelicals: Expanding the Vision of the Common Good. Grand Rapids: Wm. B. Eerdmans, 2011.

4. Pew Forum on Religion and Public Life. "Assessing a More Prominent 'Religious Left'." 5 June 2008. http://pewforum.org/Politics-and-Elections/Assessing-a-More-Prominent-ReligiousLeft.aspx (accessed on 29 May 2012).

5. Tim Chester. "Introducing Integral Mission." In Justice, Mercy and Humility: Integral Mission and the Poor, edited by Tim Chester. Waynesboro: Paternoster Press, 2002, 1-12. 
6. Al Tizon. Transformation after Lausanne: Radical Evangelical Mission in Global-Local Perspective. Eugene: Wipf \& Stock, 2008, 4-7.

7. “Evangelism in Latin America." Christianity Today, 19 December 1969, 22.

8. Samuel Escobar. "Divided Protestantism Struggles with Latin American Problems." World Vision Magazine, November 1969.

9. W. Dayton Roberts. "Latin American Protestants: Which Way Will They Go?" Christianity Today, 10 October 1969, 14-16.

10. C. Peter Wagner. Latin American Theology: Radical or Evangelical? Grand Rapids: Wm. B. Eerdmans, 1970.

11. Samuel Escobar. "Heredero de la Reforma Radical." In Hacia Una Teología Latinoamericana: Ensayos en Honor a Peter Savage, edited by C. René Padilla. San José: Editorial Caribe, 1984, 51-71.

12. Sydney Rooy. "FTL History, a Bird's-Eye View." FTL website: http://www.ftlal.org/index.php?option=com_content\&view=article\&id=58\&Itemid=60 (accessed on 29 May 2012).

13. Ondina E. Gonzalez, and Justo L. Gonzalez. Christianity in Latin America: A History. New York: Cambridge University Press, 2008.

14. Samuel Escobar. Changing Tides: Latin America \& World Mission Today; Maryknoll: Orbis, 2002.

15. Emilio A. Núñez, and William D. Taylor. Crisis in Latin America: An Evangelical Perspective, Chicago: Moody Press, 1989.

16. Luis L. Odell. "Iglesia y Sociedad en América Latina.” Cristianismo y Sociedad 1 (1963): 65-67.

17. Jose Miguez Bonino. Doing Theology in a Revolutionary Situation. Philadelphia: Fortress Press, 1975.

18. C. René Padilla. "Liberation Theology: An Appraisal." In Freedom and Discipleship: Liberation Theology in Anabaptist Perspective, edited by Daniel S. Schipani. Maryknoll: Orbis Books, 1989.

19. C. René Padilla. "Introduction: An Ecclesiology for Integral Mission." In The Local Church, Agent of Transformation: An Ecclesiology for Integral Mission, edited by Tetsunao Yamamori, and C. René Padilla. Buenos Aires: Ediciones Kairós, 2004.

20. Carl F.H. Henry. The Uneasy Conscience of Modern Fundamentalism. Grand Rapids: Wm. B. Eerdmans, 1947.

21. David O. Moberg. Inasmuch: Christian Social Responsibility in the Twentieth Century. Grand Rapids: Wm. B. Eerdmans, 1965.

22. David R. Swartz. "Left Behind: The Evangelical Left and the Limits of Evangelical Politics, 1965-1988." PhD diss., University of Notre Dame, 2008.

23. Harold Lindsell, ed. "The Wheaton Declaration." In The Church's Worldwide Mission. Waco: Word, 1966.

24. Harold Lindsell. "Precedent-setting in missions strategy." Christianity Today, 29 April 1966, 43.

25. Donald Tinder. "Urbana '70: Evangelical Student Power." Christianity Today, 29 January 1971, 29-30.

26. Richard Quebedeaux. The Young Evangelicals. New York: Harper \& Row, 1974.

27. Samuel Escobar. "Social Concern and World Evangelism." In Christ the Liberator. Downers Grove: InterVarsity Press, 1971. 
28. Gregorio Landero. "Evangelism and Social Concern." Right On! 6 (November 1974): no. 4.

29. Richard Quebedeaux. The Worldly Evangelicals. New York: Harper \& Row, 1978.

30. Billy Graham. "Evangelism As I See It." Princeton Seminary Bulletin, April 1953, 13-20.

31. Billy Graham. World Aflame; Garden City: Doubleday, 1965.

32. Jim Wallis. Revive Us Again: A Sojourner's Story. Nashville: Abingdon Press, 1983.

33. "Evangelicals on Justice: Socially Speaking..." Christianity Today, 21 December 1973, 38-39.

34. Ronald J. Sider, ed. The Chicago Declaration. Carol Stream: Creation House, 1974.

35. Paul Henry. “Evangelicals of America, Arise!” Eternity, February 1974, 12, 71, 72.

36. Marjorie Hyer. "Social and Political Activism Is Aim of Evangelical Group." Washington Post, 30 November 1973, D17.

37. Marjorie Hyer. "Evangelicals: Tackling the Gut Issues." Christian Century, 19 December 1973, 1244.

38. Roy Larson. "Historic Workshop: Evangelicals Do U-turn, Take on Social Problems.” Chicago Sun-Times, 1 December 1973.

39. James Robert Ross. "Evangelicals and Social Concern." Christian Standard, 3 February 1974, 9-10.

40. “Interview with Samuel Escobar.” Sojourners, September 1976, 15-18.

41. Stephen Knapp. "Critique: Miguez, Gutierrez: Pivotal Works,” Sojourners, September 1976, 33-37.

42. Jim Wallis. Agenda for Biblical People. San Francisco: Harper \& Row, 1976.

43. Orlando E. Costas. The Church and Its Mission: A Shattering Critique from the Third World. Wheaton: Tyndale House, 1974.

44. “Orlando Enrique Costas.” Journal of Latin American Theology 4, no. 2 (2009): 136-155.

45. “A Challenge from Evangelicals." Time, 5 August 1974.

46. C. René Padilla. Mission Between the Times. Grand Rapids: Wm. B. Eerdmans, 1985.

47. "Lausanne I: The International Congress on World Evangelism." The Lausanne Movement website. http://www.lausanne.org/lausanne-1974/lausanne-1974.html (accessed on 30 May 2012).

48. “Do We Really Need Lausanne?” Christanity Today, 15 March 1974, 36-37.

49. René Padilla. "Evangelism and the World." In Let the Earth Hear His Voice: International Congress on World Evangelization Lausanne, Switzerland, edited by J.D. Douglas. Minneapolis: World Wide Publications, 1975, 116-146.

50. Bruce Kaye. "Lausanne: An Assessment." CWN Series, 16 August 1974.

51. Samuel Escobar. "Evangelism and Man's Search for Freedom, Justice and Fulfillment." In Let the Earth Hear His Voice: International Congress on World Evangelization Lausanne, Switzerland; edited by J.D. Douglas. Minneapolis: World Wide Publications, 1975, 303-326.

52. Gerald Davis. "A Coming of Age for Evangelicals." Church Scene, 1 August 1974.

53. John A. Coleman. "Aftermath of Lausanne! Evangelism in a Changing World." New Life, 28 August 1974.

54. Athol Gill. "Christian Social Responsibility." In The New Face of Evangelicalism: A International Symposium on the Lausanne Covenant; edited by C. René Padilla. Downers Grove: InterVarsity Press, 1976, 87-102.

55. Billy Graham. "Our Mandate From Lausanne '74: An Address to the Lausanne Continuation Committee.” Christianity Today, 4 July 1975, 3-6. 
56. J.D. Douglas, ed. "Theology Implications of Radical Discipleship." In Let the Earth Hear His Voice: International Congress on World Evangelization Lausanne, Switzerland. Minneapolis: World Wide Publications, 1975, 1294.

57. C. René Padilla. "Evangelism and Social Responsibility from Wheaton '66 to Wheaton '83." In How Evangelicals Endorsed Social Responsibility (Texts on Evangelical Social Ethics 19741983 (ii) - a Commentary), edited by René Padilla, and Chris Sudgen. Nottingham: Grove Books, 1985.

58. J.D. Douglas, ed. "The Lausanne Covenant." In Let the Earth Hear His Voice: International Congress on World Evangelization Lausanne, Switzerland. Minneapolis: World Wide Publications, 1975.

59. James A. Scherer. Gospel, Church, and Kingdom: Comparative Studies in World Mission Theology. Minneapolis: Augsburg, 1987.

60. Charles Van Engen. Mission on the Way: Issues in Mission Theology; Grand Rapids, MI: Baker Books, 1996.

61. Arthur P. Johnston. The Battle for World Evangelism. Wheaton: Tyndale House, 1978.

62. C. Peter Wagner. "Lausanne Twelve Months Later." Christianity Today, 4 July 1975, 7-8.

63. Harold Lindsell. "Lausanne 74: An Appraisal." Christianity Today, 13 September 1974, 21-26.

64. "The Thailand Statement." In New Directions in Mission \& Evangelization 1: Basic Statements 1974-1991, edited by James A. Scherer and Stephan B Bevans.; Maryknoll, NY: Orbis Books, 1992, 274-275.

65. Orlando E. Costas. Christ Outside the Gate: Mission Beyond Christendom. Maryknoll: Orbis Books, 1982.

66. Klaus Bockmuehl. Evangelicals and Social Ethics: A Commentary on Article 5 of the Lausanne Covenant, translated by David T. Priestly. Downers Grove: InterVarsity Press, 1979.

67. John Stott. The Lausanne Covenant-An Exposition and Commentary. Minneapolis: World Wide Publications, 1975.

68. Vinay Samuel, and Chris Sugden, eds. The Church in Response to Human Need. Grand Rapids: Wm. B. Eerdmans, 1987.

69. C. René Padilla. "Integral Mission and its Historical Development." In Justice, Mercy and Humilty: Integral Mission and the Poor, edited by Tim Chester. Waynesboro: Paternoster Press, 2002, 42-58.

70. David Bosch. Transforming Mission: Paradigm Shifts in Theology of Mission. Maryknoll: Orbis Books, 1991.

71. Daniel Salinas. Latin American Evangelical Theology in the 1970's: The Golden Decade. Boston: Brill, 2009.

72. “Lausanne Occasional Papers: No. 2 The Willowbank Report—Gospel and Culture." Wheaton: Lausanne Committee for World Evangelization, 1978.

73. Alan Nichols. Lausanne Occasional Papers: No. 20 an Evangelical Commitment to Simple Lifestyle. Wheaton: Lausanne Committee for World Evangelization, 1980.

74. "Evangelism and Social Responsibility: An Evangelical Commitment." Wheaton: Lausanne Committee for World Evangelization, 1982. 
75. Axel R. Schäfer. Countercultural Conservatives: American Evangelicalism from the Postwar Revival to the New Christian Right. Madison: University of Wisconsin Press, 2011.

76. Albert J. Menendez. Evangelicals at the Ballot Box. Amherst: Prometheus Books, 1996.

77. David R. Swartz. "Identity Politics and the Fragmenting of the 1970s Evangelical Left." Religion and American Culture: A Journal of Interpretation 21, no. 1 (Winter 2011): 81-120.

78. Tom Sine. Mustard Seed Versus McWorld: Reinventing Life and Faith for the Future. Grand Rapids: Baker Books, 1999.

79. Robert A. Hunt. “The History of the Lausanne Movement, 1974-2010.”International Bulletin of Missionary Research, April 2011.

80. C. René Padilla. "From Lausanne I to Lausanne III.” Journal of Latin American Theology no. 25 (2010).

81. John Stott. "Twenty Years After Lausanne: Some Personal Reflections.” International Bulletin of Missionary Research, April 1995.

82. Tom and Christine Sine. "Integral Mission in Context." In Justice, Mercy and Humilty: Integral Mission and the Poor, edited by Tim Chester. Waynesboro, GA: Paternoster Press, 2002, 65-77.

83. Steve Bradbury. "Introducing the Micah Network." In Justice, Mercy and Humilty: Integral Mission and the Poor, edited by Tim Chester. Waynesboro: Paternoster Press, 2002, 13-16.

84. Joel Edwards. "Micah Challenge: The Story So Far." In Micah's Challenge: The Church's Responsibility to the Global Poor, edited by Marijke Hoek, and Justin Thacker. Colorado Springs: Paternoster, 2008, 1-12.

85. Pew Forum on Religion and Public Life. "Religion and the Issues: Results from the 2010 Annual Religion and Public Life Survey." 17 September 2010. http://pewforum.org/Politics-andElections/Few-Say-Religion-Shapes-Immigration-Environment-Views.aspx (accessed on 31 May 2012).

86. Ronald J. Sider, and Diane Knippers, eds. "For the Health of the Nation: An Evangelical Call to Civic Responsibility." In Toward an Evangelical Public Policy: Political Strategies for the Health of the Nation. Grand Rapids: Baker Books, 2005, 363-375.

87. "An Evangelical Declaration Against Torture: Protecting Human Rights in an Age of Terror." National Association of Evangelicals website. http://www.nae.net/government-relations/ endorsed-documents/409-an-evangelical-declaration-against-torture-protecting-human-rights-inan-age-of-terror (accessed on 31 May 2012).

88. "Immigration 2009." National Association of Evangelicals website. http://www.nae.net/ government-relations/ policy-resolutions/354-immigration-2009 (accessed on 31 May 2012).

89. "Lowering the Debt, Raising the Poor 2011." National Association of Evangelicals website. http://www.nae.net/government-relations/policy-resolutions/541-lowering-the-debt-raising-thepoor-2011 (accessed on 31 May 2012).

90. Barbara Bradley Hagerty. "Evangelical Leaders Urge Action on Climate Change." NPR website. 8 February 2006. http://www.npr.org/2006/02/08/5194527/evangelical-leaders-urge-action-onclimate-change (accessed on 31 May 2012).

91. "An Evangelical Manifesto: A Declaration of Evangelical Identity and Public Commitment." Evangelical Manifesto website. http://www.anevangelicalmanifesto.com/ (accessed on 31 May 2012). 
92. Tim, Keller. Generous Justice: How God's Grace Makes Us Just.New York: Dutton, 2010.

93. Mark Galli. "Making the Local Church a Hero." Christianity Today, March 2009, 32-39.

94. Timothy C. Morgan. "Purpose Driven in Rwanda." Christianity Today, October 2005, 32-36, 90-91.

95. Rob Bell, and Don Golden. Jesus Wants to Save Christians: A Manifesto for the Church in Exile. Grand Rapids: Zondervan, 2008.

96. John Green. The Faith Factor: How Religion Influences American Elections. Westport: Praeger, 2007.

97. Jim Wallis. God's Politics: Why the Right Gets It Wrong and the Left Doesn't Get It. San Francisco: HarperCollins, 2005.

98. Jim Wallis. The Great Awakening: Reviving Faith \& Politics in a Post-Religious Right America. New York: HarperCollins, 2008.

99. Shane Claiborne. The Irresistible Revolution: Living as an Ordinary Radical. Grand Rapids: Zondervan, 2006.

100. J. Matthew Sleeth. Serve God, Save the Planet: A Christian Call to Action. Grand Rapids: Zondervan, 2006.

101. Warren Bird. "Emerging Church.” Encyclopedia of Religion in America, edited by C.H. Lippy, P.W. Williams. Washington D.C.: CQ Press, 2010, 682.

102. Orlando E. Costas. Liberating News: A Theology of Contextual Evangelization. Grand Rapids: Wm. B. Eerdmans, 1989.

103. Tony Jones. The New Christians: Dispatches from the Emergent Frontier. San Francisco: JosseyBass, 2008.

104. Tom Sine. Phone conversation with author, 26 May 2012.

105. Tony Jones. Email to the author, 10 November 2011.

106. Brian McLaren. "Introduction: A Conversation about Justice." In The Justice Project, edited by Brian McLaren, Elisa Padilla, and Ashley Bunting Seeber. Grand Rapids: Baker Books, 2009, 13-20.

107. Brian McLaren. Emails to the author; 2 May 2010 and 15 November 2011.

108. "What is the Del Camino Network?" Red del Camino website. http://lareddelcamino.net/en/ images/Articles/what\%20is\%20the\%20del\%20camino\%20network_pdf (accessed on 3 June 2012).

109. Brian McLaren. Everything Must Change: Jesus, Global Crises, and a Revolution of Hope. Nashville: Thomas Nelson, 2007.

110. Brian McLaren. "Family Letter From Latin America.” BrianMcLaren.net. http://brianmclaren.net/ archives/resources-archive/family-letter-from-latin-america.html (accessed on 3 June 2012).

111. Brian McLaren. "Emergent Past and Future." Seminar talk, Emergent Convention, Nashville, TN, May 2005. Audio CD.

112. Brian McLaren. "Everything Must Change Tour 2008." BrianMcLaren.net. http://www.brianmclaren.net/archives/schedule/everything-must/ (accessed on 3 June 2012).

(C) 2012 by the author; licensee MDPI, Basel, Switzerland. This article is an open access article distributed under the terms and conditions of the Creative Commons Attribution license (http://creativecommons.org/licenses/by/3.0/). 